\title{
Antibiotic Resistance of Enteropathogen, Enteroinvasive and Shigatoxinogen E. coli Isolated in Fish from Layo Farm
}

\author{
Kouadio-Ngbesso ${ }^{1 *}$, Konan $\mathrm{F}^{2}$, Blé $\mathrm{Y}^{3}$, Kouamé-Sina $\mathrm{SM}^{2}$, Adingra $\mathrm{A}^{1}$, \\ Guessennd $\mathrm{N}^{2}$ and Dadié $\mathrm{AT}^{4}$ \\ ${ }^{1}$ Centre de Recherches Oceanologiques, BP V 18 Abidjan, Côte d'Ivoire \\ ${ }^{2}$ Institut Pasteur de Côte d'Ivoire, 01 BP 490 Abidjan 0,1Côte d'Ivoire \\ ${ }^{3}$ Université Polytechnique de Man, UFR-IAFE (Ingenierie, Agronomie Forestière et \\ Research Article \\ Volume 5 Issue 3 \\ Received Date: August 09, 2020 \\ Published Date: August 26, 2020 \\ DOI: $10.23880 /$ oajmb-16000166
} Environnement, BP 20 Man

${ }^{4}$ Université Nangui Abrogoua. Laboratoire de Biotechnologie et Microbiologie des Aliments, UFR-STA, 02 BP 801 Abidjan 02, Côte d'Ivoire

*Corresponding author: Kouadio-Ngbesso Nadège, Centre de Recherches Oceanologiques, BP V 18 Abidjan, Côte d'Ivoire, Tel : +22507979182; Email: ah_nadege1@yahoo.fr

\section{Abstract}

The objective of this work was to determine the antibiotic resistance and the resistance phenotypes of pathogenic strains of $E$. coli isolated from gills and viscera of fish from Layo ponds in "One Health" approach. Eleven (11) strains of $E$. coli belonging to the pathovars Enteropathogenic E. coli $(\mathrm{EPEC}=4)$, Shiga toxinogenic $E$ coli $(\mathrm{STEC}=5)$, Enteroinvasive E. coli (EIEC=2) from our previous work on gills (7) and viscera (4) of fish Oreochromis niloticus, was tested by Müller-Hinton agar diffusion method. Nineteen (19) antibiotics divided into 9 differents families (Penicillins, Cephalosporins, Monobactam, Carbapenems, Quinolone, Aminoside, Cyclin, Phenicol, Phosphonique Acid) were tested. The results shown that all strains (100\%) were resistant to amoxicillin, amoxicillin + clavulanic acid and piperacillin tazobactam. Resistance was also observed with $3^{\text {rd }}$ generation antibiotics (CTX, CAZ, FEP, TCG) and monobactam (ATM) in EPEC and STEC strains only. Fifty percent (50\%) of resistance were observed to CTX and CAZ and 25\% to Monobactam in EPECstrains. Fourty percent (40\%) of resistance were observed to CTX and CAZ and 20\% to Monobactam in STEC strains. More than half of strains studied were resistant to fosfomycin (63\%). The resistance phenotype observed among E. coli pathovars (EPEC, EIEC and STEC) revealed that, 18\% of EPEC and $9 \%$ of EIEC had a high level of penicillinase phenotype. A high level of cephalosporinase phenotype was represented respectively in $9 \%$ of EPEC and STEC. These resistances have been observed although antibiotics are not used in this farm reflecting the pollution of the fish living environment (supply water). Efforts are needed to promote more judicious use of prophylactic antibiotics in both human and animal health to reduce their presence in environment. If environment and everything that lives in are doing well, people will be doing well too.

Keywords: Antibiotics; Enteropathogen; Enteroinvasive; Shigatoxinogen; E. coli; Fish 


\section{Open Access Journal of Microbiology \& Biotechnology}

\section{Introduction}

The Layo aquaculture station located in the department of Dabou, is an experimental site in which some ponds are supplied directly by water from the Ebrie lagoon and by groundwater. Severalstudies have shown that the waters of the Ebrie lagoon are polluted due to human activities taking place in the surrounding area [1-4]. During the month of October 1999, massive fish mortalities were observed in 2 sectors of this lagoon located in Dabou and Jacqueville departments. In May 2013, this phenomenon became more pronounced, leading to the closure of fishing and some aquaculture farms located in the vicinity of this lagoon. Recent work [5] on the waters in the ponds of this experimental farm revealed their strong contaminations with faecal coliforms and Vibrio. Our recent studies conducted [6], revealed the presence of enteropathogenic, toxigenic and enteroinvasive strains of E. coli in the gills and viscera of fish Oreochromis niloticus caught in Layo ponds, an aquaculture station. The presence of multiresistant germs in environment has also been detected $[7,8]$. Antibacterial resistance is a real public health problem. They are found in humans [9]; animals [10,11]; and also in the environment [12]. Antibiotic-resistant bacteria of animal origin can be transmitted to humans through the ingestion of contaminated food, direct contact with animals or their environment [13]. This antibiotic resistance is a major issue not only for animal health but also for human health. Indeed, human and animal sharing the same environment and the same antibiotics, human health and animal health are interconnected with the health of ecosystems in which they coexist under the "One Health" approach [14]. Then, many pathogenic bacteria are common to both humans and animals, and the same families of antibiotics are therefore used in both veterinary and human medicine [15].

The objective of this work was to determine the antibiotic resistance and the resistance phenotype of pathogenic strains of $E$. coli isolated from gills and viscera of fish from Layo ponds in "One Health" approach.

\section{Material and Methods}

Eleven (11) strains of $E$. coli belonging to the pathovars Enteropathogenic E. coli $(\mathrm{EPEC}=4)$, Shiga toxinogenic $E$ coli (STEC=5), Enteroinvasive E. coli $(\mathrm{EIEC}=2$ ) from our previous work on gills (7) and viscera (4) of fish Oreochromis niloticus, was tested by Müller-Hinton agar diffusion method according to Antibiogram Committee of French Society of Microbiology [16]. According to EUCAST-CASFM recommendations on antibiotics used in case of infection with enterobacteria and in view of the multi- drug resistance observed in recent years, 19 antibiotics divided into 9 differents families (Penicillins,
Cephalosporins, Monobactam, Carbapenems, Quinolone, Aminoside, Cyclin, Phenicol, Phosphonique Acid) were tested. These are: Amoxicillin (25 $\mu \mathrm{g})$, Amoxicillin + clavulanic acid $(20 / 10 \mu \mathrm{g})$, Cefotaxim $(30 \mu \mathrm{g})$, ceftazidim (30g), Ciprofloxacin $(5 \mu \mathrm{g})$, Cefoxitin $(30 \mu \mathrm{g})$, Aztreonam (30 $\mathrm{gg})$, Nalidixic Acid (30 $\mu \mathrm{g})$, Chloramphenicol $(30 \mu \mathrm{g})$, Imipenem $(10 \mu \mathrm{g})$, Ticarcilline + acide clavulanique (75/10 $\mu \mathrm{g})$, Piperacillin-Tazobactam $(100 / 10 \mu \mathrm{g})$, Ciprofloxacine $(5 \mu \mathrm{g})$, Gentamycine $(10 \mu \mathrm{g})$, Netilmicin $(10 \mu \mathrm{g})$ et Tigecyclin $(15 \mu \mathrm{g})$, Fosfomycin $(200 \mu \mathrm{g})$, Amykacin $(30 \mu \mathrm{g})$ (Bio-Rad, France). The reference strain Escherichia coli ATCC 25922 were used as a control. Isolates were classified as susceptible or resistant to the drug (isolates showing intermediate susceptibility were considered as resistant) according to the EUCAST-CASFM [17].

\section{Antibiotyping Method}

The antibiotyping method involves the simultaneous presence of one or more antibiotic resistance markers. A strain may not wear a resistance marker or wear one or more [18]. When studying the susceptibility of a strain to several antibiotics, its resistance phenotype to antibiotics was determined. If the strain expresses only natural resistances, it is said to belong to the "wild" or sensitive phenotype. If its acquired resistances have changed its sensitivity, it expresses a "phenotype of resistance" that can be identified and whose mechanism must be determined. This phenotype is often referred to as initials of antibiotics that have become inactive. A strain is described as multidrug resistant when it is resistant to three antibiotics of different families $[19,20]$.

\section{Resultants}

\section{Antibiotic Resistance}

In this study, nineteen antibiotics divided in 9 families were testing. Antimicrobial susceptibility testing revealed that $E$. coli pathovars were resistant at least to one antibiotic tested. All strains (100\%) were resistant to amoxicillin, amoxicillin + clavulanic acid and piperacillin tazobactam. They were also resistant to fosfomycin at $63.7 \%$ and to cefoxitin at $45.5 \%$. Eighteen percent $(18.18 \%)$ of strains were resistant to Aztreonam and Cefotaxim which is $3 \mathrm{G}$ cephalosporins. Also, nine percent $(9 \%)$ of strains were Tigecycline resistant which is a 3G Cyclin (Figure 1). All strains (2 strains) of EIEC were resistant to TIC and TCC while fifty percent ( 2 strains) of EPEC strains were resistant to. All strains (5) of STEC were sensitive to TIC and TCC. All EIEC strains were sensitive to others 8 antibiotics families tested. The resistance observed with Aztreonam provided to one (1) strain (20\%) of STEC and one (1) strain (25\%) of EPEC. The resistance of Tigecycline provided to a strain (1) of EPEC (Table 1). 


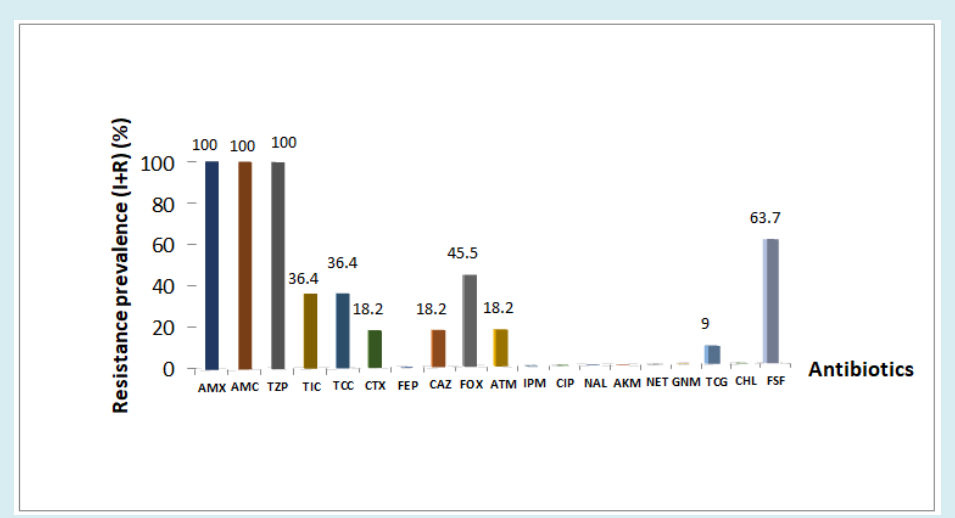

Figure 1: Antibiotic resistance profile of pathogenics E. coli strains.

Legend: $\mathrm{AMC}=$ amoxicillin-clavulanic acid, $\mathrm{AMX}=$ amoxicillin, $\mathrm{CTX}=$ cefotaxime, $\mathrm{ATM}=$ aztreoname, $\mathrm{IPM}=$ imipenem, $\mathrm{FEP}=$ cefepime, $\mathrm{CHL}=$ chloramphenicol, $\mathrm{CIP}=$ ciprofloxacin, $\mathrm{NAL}=$ nalidixic acid, $\mathrm{GNM}$ = gentamicin, $\mathrm{TZP}=$ piperacillin-tazobactam, NET = netilmicin, TCC $=$ ticarcilline + acide clavulanique, TIC= ticarcilline , FSF= fosfomycin, TCG= tigecyclin, CAZ= ceftazidim, AKM= amykacin , FOX= cefoxitin, $\mathrm{I}=$ intermediate, and $\mathrm{R}=$ resistant

\begin{tabular}{|c|c|c|c|c|c|}
\hline & & & \multicolumn{3}{|c|}{ Resistance N (\%) } \\
\hline & & & \multicolumn{3}{|c|}{ Pathogenics E. coli } \\
\hline \multicolumn{2}{|c|}{ Antibiotics Families } & Antibiotics & EIEC & EPEC & STEC \\
\hline \multirow{19}{*}{ 总 } & \multirow{5}{*}{ Penicillins } & AMX & $2(100)$ & $4(100)$ & $5(100)$ \\
\hline & & $\mathrm{AMC}$ & $2(100)$ & $4(100)$ & $5(100)$ \\
\hline & & TZP & $2(100)$ & $4(100)$ & $5(100)$ \\
\hline & & TIC & $2(100)$ & $2(50)$ & $0(0)$ \\
\hline & & $\mathrm{TCC}$ & $2(100)$ & $2(50)$ & $0(0)$ \\
\hline & \multirow{3}{*}{$\begin{array}{c}\text { Cephalosporin } \\
\text { (3G) }\end{array}$} & CTX & $0(0)$ & $1(25)$ & $1(20)$ \\
\hline & & $\mathrm{CAZ}$ & $0(0)$ & $1(25)$ & $1(20)$ \\
\hline & & FEP & $0(0)$ & $0(0)$ & $0(0)$ \\
\hline & $\begin{array}{c}\text { Cephalosporin } \\
\text { (2G) }\end{array}$ & FOX & $0(0)$ & $1(25)$ & $4(80)$ \\
\hline & Monobactam & ATM & $0(0)$ & $1(25)$ & $1(20)$ \\
\hline & Carbapenems & IPM & $0(0)$ & $0(0)$ & $0(0)$ \\
\hline & \multirow{2}{*}{ Quinolones } & CIP & $0(0)$ & $0(0)$ & $0(0)$ \\
\hline & & NAL & $0(0)$ & $0(0)$ & $0(0)$ \\
\hline & \multirow{3}{*}{ Aminoglycosides } & $\mathrm{AKM}$ & $0(0)$ & $0(0)$ & $0(0)$ \\
\hline & & NET & $0(0)$ & $0(0)$ & $0(0)$ \\
\hline & & GNM & $0(0)$ & $0(0)$ & $0(0)$ \\
\hline & Cyclins & TCG & $0(0)$ & $1(25)$ & $0(0)$ \\
\hline & Phenicols & $\mathrm{CHL}$ & $0(0)$ & $0(0)$ & $0(0)$ \\
\hline & Phosphonic acid & FSF & $2(100)$ & $3(75)$ & $2(40)$ \\
\hline
\end{tabular}

Table 1: Distribution of resistance by pathogenics $E$ coli.

Legend: $\mathrm{AMC}=$ amoxicillin-clavulanic acid, $\mathrm{AMX}=$ amoxicillin, $\mathrm{CTX}=$ cefotaxime, $\mathrm{ATM}=$ aztreoname, $\mathrm{IPM}=$ imipenem, $\mathrm{FEP}=$ cefepime, $\mathrm{CHL}=$ chloramphenicol, $\mathrm{CIP}=$ ciprofloxacin, $\mathrm{NAL}=$ nalidixic acid, $\mathrm{GNM}=$ gentamicin, $\mathrm{TZP}=$ piperacillin-tazobactam, $\mathrm{NET}$ = netilmicin, $\mathrm{TCC}=$ ticarcilline + acide clavulanique, $\mathrm{TIC}=$ ticarcilline, $\mathrm{FSF}=$ fosfomycin, $\mathrm{TCG}=$ tigecyclin, $\mathrm{CAZ}=$ ceftazidim, $\mathrm{AKM}=$ amykacin , FOX= cefoxitin, G= generation, EPEC = enteropathogenic E. coli, EIEC = enteroinvasive $E$. coli, $\mathrm{STEC}=$ shigatoxinogen E. coli 


\section{Open Access Journal of Microbiology \& Biotechnology}

\section{Phenotypic Resistance}

The results of the study show 5 levels of phenotypic resistance. Phenotypics resistances are distributed in three groups that are Penicillin (high and low penicillinase resistance), Aminosides (wild phenotype) and Betalactamin (wild phenotype and high cephalosporinase resistance). A high level of penicillinase resistance (PASEHN) was detected in 3 on 11 strains $(27.2 \%)$. All strains $(100 \%)$ have Aminoside wild phenotype (AM00). A high level of Cephalosporinase (HCASE) resistance was observed in 2 strains (18.18\%). The wild-type betalactamin phenotype were present in 8 strains (72.72\%) (Table 2). The resistance phenotype observed among E. coli pathovars (EPEC, EIEC and STEC) revealed that, 18\% (2 strains) of EPEC and 9\% (1 strain) of EIEC had a high level of penicillinase phenotype. A high level of cephalosporinase phenotype was represented respectively in 9\% (1 strain respectively) of EPEC and STEC (Table 2).

\begin{tabular}{|c|c|c|c|c|}
\hline \multirow{2}{*}{ Resistance phenotypes } & \multicolumn{3}{|c|}{ E. coli pathovars $N(\%)$} & \multirow{2}{*}{$\begin{array}{c}\text { Total } \\
\text { N (\%) }\end{array}$} \\
\hline & EPEC (4) & STEC (5) & EIEC (2) & \\
\hline PHN & $2(18.18)$ & $0(0)$ & $1(9.09)$ & $3(27.27)$ \\
\hline PBN & $2(18.18)$ & $5(45.45)$ & $1(9.09)$ & $8(72.72)$ \\
\hline PSBL & $3(27.2)$ & $3(27.2)$ & $2(18.18)$ & $8(72.72)$ \\
\hline PSA & $4(36.36)$ & $5(45.45)$ & $2(18.18)$ & $11(100)$ \\
\hline HCASE & $1(9.09)$ & $1(9.09)$ & $0(0)$ & $2(18.18)$ \\
\hline $\mathrm{PBN}+\mathrm{PS} \beta \mathrm{L}+\mathrm{PSA}$ & $1(9.09)$ & $4(36.36)$ & $1(9.09)$ & $6(54.54)$ \\
\hline $\mathrm{PHN}+\mathrm{PS} \beta \mathrm{L}+\mathrm{PSA}$ & $2(18.18)$ & $0(0)$ & $1(9.09)$ & $3(27.27)$ \\
\hline $\mathrm{PBN}+\mathrm{HCASE}+\mathrm{PSA}$ & $1(9.09)$ & $1(9.09)$ & $0(0)$ & $2(18.18)$ \\
\hline
\end{tabular}

Table 2: Distribution of resistance phenotypes prevalence by E. coli pathovars.

Legend: PSßL = ß-lactamins wild phenotype, $\mathrm{PBN}=$ low-level penicillinases, $\mathrm{PHN}=$ high-level penicillinases, $\mathrm{HCASE}=$ high cephalosporinases, $\mathrm{PSA}=$ aminoglycosides wild phenotype, $\mathrm{EPEC}=$ enteropathogenic $E$. coli, $\mathrm{EIEC}=$ enteroinvasive $E$. coli, STEC = shigatoxinogen $E$. coli

\section{Discussion}

Penicillins are part of the family of antibiotics most used in therapy. A resistance of virulent strains expressed at $100 \%$ to amoxicillin, amoxicillin + clavulanic acid and to piperacillin tazobactam during this study, shows a high level of risk because these antibiotics are used to treat bacterial infections affecting the lower respiratory tract (lungs), urinary tract (kidneys and bladder), abdomen, skin or blood. Data from several previous studies have shown that penicillin resistance is common in E. coli isolated from food animals [21-25].

A high resistance levels to amoxicillin (77.4\%) and amoxicillin-clavulanic acid (77.4\%) were observed in the study of Konate [9] in diarrheagenic Escherichia coli responsible for infantile gastroenteritis in Ouagadougou, Burkina faso. A similar level of resistance to amoxicillinclavulanic acid $(73.3 \%)$ was observed to, in the study of Dembele, et al. [26] in enteropathogenic Escherichia coli and E. coli 0157 isolated from diarrheal children in rural area of Burkina Faso.

Resistance was also observed with 3rd generation antibiotics (CTX, CAZ, FEP, TCG) and monobactam (ATM) during this study. These are generally used in the treatment of serious infections. Also, more than $63 \%$ of the strains exhibited resistance to Fosfomycin, which is used in combination in the treatment of serious infections with multidrug-resistant bacteria. All the strains studied (100\%) had the wild-type aminoglycoside phenotype and therefore sensitive. It is important to note that Aminoglycosides are among the antibiotics used in the management of $E$. coli gastroenteritis [9]. Of all strains, 18\% of EPECs and 9\% of ECEIs possessed the high-resistance penicillinase phenotype. There is a real public health risk as the detection of antibiotic resistance genes in bacteria isolated from aquaculture products that can be transferred to the human microbiota have been reported [10]. Fish farmers normally add antibiotics into feed as growth promoters, for therapeutic and prophylactic purposes to supplement this increasing demand [27]. Antibiotics used for animals either for therapy, prophylactic or growth promotion purposes at a sub therapeutic dose can result in transfer of resistant genes from animals to humans and thereby establishing a reservoir of resistant microbes [28,29]. Although the use of antibiotics is not practiced at the Layo fish farm, although no feed is added, high resistance has been detected in strains of $E$. coli from fish. These contaminations could be due to water runoff from surrounding farms and food crop areas (use of ATB), to the lagoon which is a receptacle of urban waste $[30-32,5]$ including those in hospitals, especially since these waters communicate with the groundwater supplying the ponds. There are also the hygienic habits of workers and residents and also the way the fish are fed, which could explain these contaminations. Huang's [33] work at a domestic aquaculture farm with no known history of antibiotic application, also 


\section{Open Access Journal of Microbiology \& Biotechnology}

revealed the existence of a rich profile of antibiotic resistant bacteria in pond water samples, on the skin, in the intestines and in fish feed. The microbial flora of freshly captured fish is usually a reflection of the environment in which it was harvested. Generally, ponds and rivers that harbor fish may be the source of the microorganisms due to indiscriminate dumping of human and animal excreta as well as other environmental wastes into natural water bodies or washing of excreta from land into water during the rainy season [34]. Free roaming animals especially dogs and birds in Layo site, could contribute to fecal contamination of surface water and ponds $[35,36]$. These microorganisms from feces or environmental waste contain antibiotic resistant gene that may disseminate and contaminate the aquatic environment.

\section{Conclusion}

All strains of enteropathogenic, shigatoxigenic and enteroinvasive E. coli providing from gills and viscera of Oreochromis niloticus caught in the ponds of the aquaculture station of Layo were resistant to amoxicillin, amoxicillin + clavulanic acid and to piperacillin tazobactam. Resistance was also observed with 3rd generation antibiotics (CTX, CAZ, FEP, TCG) and monobactam (ATM). More than half of strains studied were resistant to fosfomycin. These resistances have been observed although antibiotics are not used in this farm reflecting the pollution of the fish living environment. Efforts are needed to promote more judicious use of prophylactic antibiotics in both human and animal health to reduce their presence in environment. If environment and everything that lives in are doing well, people will be doing well too.

\section{References}

1. Kouassi AM, Guiral D, Dosso M (1990) Variations saisonnières de la contamination microbienne de la zone urbaine d'une lagune tropicale estuarienne cas de la ville d'Abidjan (Côte d'Ivoire). Rev Hydrobiol trop 23(3): 181194.

2. Adingra AA (2007) Pollutions organique et bacterienne des eaux de Côte d'Ivoire: cas d'une zone rurale (station aquacole experimentale de Layo) et d'une zone urbaine lagune Ebrie. Thèse de Doctorat, Universite de Cocody, Abidjan (Côte d'Ivoire), pp: 184.

3. Kone B, Doumbia M, Adji FX (2007) Approche ecosystemique à la gestion des maladies diarrheiques en milieu periurbain: cas d'un village lagunaire dans la commune de Yopougon (Abidjan, Côte d'Ivoire). Projet de recherche Centre Suisse de Recherches Scientifiques en Côte d'Ivoire, rapport final, pp : 81.

4. Tuo AD, Yeo KM, Soro MB, Trokourey A, Bokra Y (2013) Contamination by nutrientsand heavy metals in the
Ebrie Lagoon (Abidjan, Ivory Coast). Res J Environ Toxico 6: 198-209.

5. Toule AC, Adingra AA, Kouadio-N'Gbesso N, Kambire O, Koffi-Nevry R, et al. (2017) Caracterisations physicochimiques et bacteriologiques des eaux des stations aquacoles de Layo et de Jacqueville (Lagune Ebrie, Côte d'Ivoire). Int J Biol Chem Sci 11(6): 2842-2855.

6. Kouadio-Ngbesso N, Kouame-Sina SM, Koffi AR, Toule AC, Adingra AA, et al. (2919) Shiga toxigenic, Enteroinvasive and Enteropathogenic Escherichia coli in Fish from Experimental Fish Farm (Layo), Côte d'Ivoire. Afr J Microbiol Res 13(23): 369-375.

7. Guessennd NK, Ouattara MB, Ouattara ND, Nevry RK, Gbonon V, et al. (2013) Etude des bacteries multiresistantes des effluents hospitaliers d'un centre hospitalier et universitaire (CHU) de la ville d'Abidjan (Côte d'Ivoire). Journal of Applied Biosciences 69: 54565464.

8. Kambire 0 , Adingra AA, Yao KM, Sika AE, Djeke S, et al. (2019) Antimicrobial resistance of enterotoxigenic Escherichia coli strains isolated from Aby lagoon in Ivory Coast. J Microbiol Biotech Food Sci 9(1): 111-114.

9. Konate Ali, Dembele R, Kagambèga A, Soulama I, Kabore Wendpoulomde AD, et al. (2017) Molecular characterization of diarrheagenic Escherichia coli in children less than 5 years of age with diarrhea in Ouagadougou, Burkina faso. Eur J Microbiol Immunol 7 (3): 220-228.

10. Miranda CD, Godoy FA, Lee MR (2018) Current Status of the Use of Antibiotics and the Antimicrobial Resistance in the Chilean Salmon Farms. Front Microbiol 9: 1284.

11. Bollache L, Bardet E, Depret G, Motreuil S, Neuwirth C, et al. (2019) Dissemination of CTX-M-Producing Escherichia coli in Freshwater Fishes from a French Watershed (Burgundy). Front Microbiol 9: 3239.

12. Huang Y, Zhang Lu, Wang HH (2015) Identification of a new tetracycline resistance determinant tet 47 from fish intestine. J Food Prot 78(8): 1581-1585.

13. Barton MD (2000) Antibiotic use in animal feed and its impact on human health. Nutr Res Rev 13(2): 279-299.

14. Chardon H, Brugère H (2014) Centre d'Information des Viandes (CIV) Usages des antibiotiques en elevage et filières viandes pp: 34.

15. Sanders P (2005) L'antibioresistance en medecine veterinaire: enjeux de sante publique et de sante animale. Bull Acad Vet France 158 (2): 137-143. 


\section{Open Access Journal of Microbiology \& Biotechnology}

16. CASFM (2018) Comite de l'Antibiogramme de la Societe Française de Microbiologie. EUCAST (European Committee on Antimicrobial Susceptibility Testing). Recommandations pp: 133.

17. EUCAST-CASFM (2019) Comite de l'antibiogramme de Societe Française de Microbiologie. Recommandations 2: 142 .

18. YeX, Wang X, Fan Y, Peng Y, Li L, et al. (2016) Genotypic and phenotypic markers of livestock-associated methicillinresistant Staphylococcus aureus CC9 in humans. Appl Environ Microbiol 82(13): 3892- 3899.

19. Guessennd N, Kacou-N'Douba A, Gbonon V, Yapi D, Ekaza E, et al. (2008) Prevalence et profil de resistance des enterobacteries productrices de $\beta$-lactamases à spectre elargi (BLSE) à Abidjan Côte d'Ivoire de 2005 à 2006. J Sci Pharm Biol 9: 63-70.

20. Kamga HG, Nzengang R, Toukam M, Sando Z, Shiro SK (2014) Phenotypes de resistance des souches d'Escherichia coli responsables des infections urinaires communautaires dans la ville de Yaounde (Cameroun). Afr J Pathol Microbiol 3: 1-4.

21. Jouini A, Ben Slama K, Saenz Y, Klibi N, Costa D, et al. (2009) Detection of multiple-antimicrobial resistance and characterization of the implicated genes in Escherichia coli isolates from foods of animal origin in Tunis. J Food Prot 72(5): 1082-1088.

22. Srinivasan V, Gillespie BE, Lewis MJ, Nguyen LT, Headrick SI, et al. (2007) Phenotypic and genotypic antimicrobial resistance patterns of Escherichia coli isolated from dairy cows with mastitis. Vet Microbiol 124(3-4): 319-328.

23. Van TTH, Chin J, Chapman T, Tran LT, Coloe PJ (2008) Safety of raw meat and shellfish in Vietnam: an analysis of Escherichia coli isolations for antibiotic resistance and virulence genes. Int J Food Microbiol 124(3): 217-223.

24. Vasilakopoulou A, Psichogiou M, Tzouvelekis L, Tassios PT, Kosmidis C, et al. (2009) Prevalence and characterization of class 1 integrons in Escherichia coli of poultry and human origin. Foodborne Pathog Dis 6(10): 1211-1218.

25. Nilla SS, Khan Md AR, Khan Md MR, Ahsan DA, Mustafa Md G (2012) Bacteriological Quality of Marketed Mola Fish, Amblypharyngodon Mola From Dhaka Metropolis. Bangladesh J Zool 40(1): 77-88.
26. Dembele R, Bonkoungou IJO, Konate A, Bsadjo Tchamba G, Ibrahim Bawa H, et al. (2015) Serotyping and antibiotic resistance of enteropathogenic Escherichia coli and E. coli 0157 isolated from diarrheal children in rural area of Burkina Faso. Afr J Microbiol Res 9(14): 1053-1059.

27. FAO (2005) Responsible Use of Antibiotics in Aquaculture. Food and Agriculture Organization of the United Nations Rome 469: 97.

28. Angulo FJ, Nunnery JA, Bair HD (2004) Antimicrobial resistance in zoonotic enteric pathogens. Rev Sci Tech 23(2): 485-496.

29. Maripandi A, l-Salamah AA (2010) Multiple- antibiotic resistance and plasmid profiles of Salmonella enteritidis isolated from retail chicken meats. Am J Food Technol 5(4): 260-268.

30. Adingra AA, Kouassi AM (2011) Pollution en lagune Ebrie et ses impacts sur l'environnement et les populations riveraines. F Tech \& Doc Vulg: 48-53.

31. Barthelemy N (2012) La pollution de la lagune Ebrie :la berge lagunaire d'Abobo-Doume. CERAP et Universite de Bouake. DEESS en ethique economique et developpement durable.

32. Julien CK, Gabaze GAA, Kouame K, Stephane KK, Bernard YO, et al. (2014): International Journal of Tropical Disease \& Health 4(5):608-620.

33. Huang Y (2014) Antibiotic Resistance in Aquaculture Production. Ph.D. dissertation, The Ohio State University, Columbus, $\mathrm{OH}$.

34. Cabral JPS (2010) Water microbiology, bacterial pathogens and water. Int J Environ Res Pub Health 7(10): 3657-3703.

35. Green HC, Dick LK, Gilpin B, Samadpour M, Field KG (2012) Genetic markers for rapid PCR- based identification of gull, canada goose, duck and chicken fecal contamination in water. Appl Environ Microbiol 78(2): 503-510.

36. Mauffret A, Caprais MP, Gourmelon M (2012) Relevance of bacteroidales and F-specific RNA bacteriophages for efficient fecal contamination tracking at the level of a catchment in France. Appl Environ Microbiol 78(15): 5143-5152. 